\title{
Production Of Bioethanol From Different Leaves Waste And Performance And Emission Characteristics Of Single Cylinder Cl Engine
}

Sreenivas Reddy Bathula ( $\sim$ jaishwa@gmail.com )

https://orcid.org/0000-0001-5910-2819

\section{Vikas S. Ballary}

Bapuji Institute of Engineering and Technology

S. Kumarappa

Bapuji Institute of Engineering and Technology

A.M. Guruchethan

Bapuji Institute of Engineering and Technology

Harika Mali

Adama Science and Technology University

Research

Keywords: Saccharomyces cerevisiae, Leaves waste, Fermentation, Diesel engine.

Posted Date: June 30th, 2020

DOl: https://doi.org/10.21203/rs.3.rs-35231/v1

License: (9) This work is licensed under a Creative Commons Attribution 4.0 International License. Read Full License 


\section{Abstract}

Background: The need of bioethanol is being increased nowadays; hence the production of bioethanol must be increased using cheaper and eco-friendly raw materials. Based on these criteria, different leaves wastes are considered as cheaper and eco-friendly. In the present study selected tree leaves wastes such as Rain tree, Jackfruit tree, Mango tree and Singapore cherry tree leaves waste were used as raw materials to produce bioethanol by using Saccharomyces cerevisiae (yeast). The operating conditions are $\mathrm{pH} 6.5$, temperature $27 \pm 2^{\circ} \mathrm{C}$, speed $80 \mathrm{rpm}$, fermentation period 10 days. Also an attempt has been made to find out the suitability of extracted bioethanol as a fuel in $\mathrm{Cl}$ engine.

Results: Experimental work on performance and emission characteristics of ethanol blended diesel fuel was conducted on single cylinder four stroke $\mathrm{Cl}$ engines at operating pressure $210 \mathrm{bar}$. The results obtained from this work shows that the higher rate of ethanol can be produced through fermentation of wet Jackfruit tree leaves, which gives good percentage of ethanol as compared to other tree leaves wastes.

Conclusions: The conversion of waste into fuel, which forms an attractive solution towards both waste management and Biofuels generation.This study concludes that the Jackfruit tree leaves contain rich fermentable sugar can be converted into useful products like bioethanol that can serve as an alternative energy source.

\section{Background}

The rapid depletions of fossil fuel create negative impact on our environment as greenhouse gas emissions are harmful. The need of fuel is increased because of increase in the vehicles and industries. By using biofuels greenhouse gas emissions are reduced. The production of bio-fuels from plant waste gives an attractive solution towards the waste management and energy generation. The bioethanol produced from feed stocks such as fruits rind part, barley, wheat, etc. In this present study the feed stocks selected are plant wastes such as Rain tree leaves, Jackfruit leaves as possible resources by conversion of plant wastes to fuel [1].

The use of starch and sugar from cassava, corn, and sugar cane are basically human food which leads to the food crisis problem. Agro-industrial bio-fuel comprised on lignocellulose biomass is an inexpensive, renewable, abundant and obtained from the non-food resource [2].

The production of ethanol from leaves involves two stages 1) Hydrolysis of biomass 2) Ethanol fermentation. Hydrolysis of Biomass can be done by using acid or enzyme catalyst. Using acid for hydrolysis produces hazardous environmental acid wastes and also causes difficulties in recovery of sugars. Enzymatic Hydrolysis is environmental friendly and efficient way to convert lignocellulose to bioethanol. The fermentation process is achieved from Saccharomyces cerevisiae. Saccharomyces cerevisiae is widely known organism that can utilize glucose and xylose for ethanol fermentation [3]. Because of more latent heat of vaporization and oxygen content, bioethanol produced from the 
fermentation process are having high octane number and it is less polluting compared to Diesel. Because of their longevity, regeneration after cut-off the leaves are considered as one of the most suitable energy crops.

Samanea saman (Rain Tree) is a species of flowering tree in the Albizia family. The common name for Raintree includes Saman, monkey pod, giant thibet, ingasaman, cow tamarind, East Indian walnut, soar and suar. Artocarpus heterophyllus (Jackfruit) trees belongs to the Moraceae family. The jackfruit trees grow in India, Bangladesh and other parts of Southeast Asia. Jackfruit tree leaves are rich in starch and protein. Muntingia calabura (Singapore cherry) trees belong to a Muntingiaceae family [4]. The common name includes Jamaican cherry, panama berry, Singapore cherry. These thrive in poor soil, able to tolerate acid and alkaline condition and drought. Mangifera indica (Mango) trees belong to Anacardiaceae family. These trees belong to mangefera genus. These leaves contain $3-15 \%$ of lignin and $40 \%$ of cellulose.

Hence in our present study leaves waste are considered as raw material for the production bioethanol. This bioethanol is mixed with diesel at different percentages of blends [5].

\section{Results And Discussion}

\subsection{Essay of ethanol from both Jackfruit and Rain tree leaves}

After fermentation ethanol obtained from both Jackfruit and Rain tree leaves was estimated by GC-MS method. Description of the samples and estimated ethanol percentages were given in Table 1 and 2 . The two bar graphs shown in Figs. 1 and 2 represents type of samples and ethanol percentage. 
Table 1

Ethanol percentage identified by GC-MS after fermentation in Jackfruit leaves sample.

\begin{tabular}{|ll|}
\hline Jackfruit Leaves Sample & Ethanol Assay (\%) \\
\hline 1)Wet Jackfruit & 4.34 \\
\hline 2)Dry Jackfruit & 1.60 \\
\hline 3)Dry Jackfruit $+\mathrm{NaOH}$ & 2.27 \\
\hline 4)Dry Jackfruit $+\mathrm{NaOH}+\mathrm{HS}$ & 2.51 \\
\hline 5)Dry Jackfruit $+\mathrm{Na}_{2} \mathrm{SO}_{4}$ & 3.15 \\
\hline 6)Dry Jackfruit $+\mathrm{Na}_{2} \mathrm{SO}_{4}+\mathrm{HS}$ & 3.33 \\
\hline 7)Dry Jackfruit $+\mathrm{NaOH}+\mathrm{Na}_{2} \mathrm{SO}_{4}$ & 3.51 \\
\hline 8)Dry Jackfruit $+\mathrm{NaOH}+\mathrm{Na}_{2} \mathrm{SO}_{4}+\mathrm{HS}$ & 4.23 \\
\hline 9)Dry Jackfruit $+\mathrm{HS}$ & 1.93 \\
\hline
\end{tabular}

Table 2

Ethanol percentage by GC-MS after fermentation in Rain tree leaves sample

\begin{tabular}{|l|l|}
\hline Rain tree Leaves Sample & Ethanol Assay (\%) \\
\hline 1)Wet Rain tree & 3.52 \\
\hline 2)Dry Rain tree & 0.97 \\
\hline 3)Dry Rain tree $+\mathrm{NaOH}$ & 1.04 \\
\hline 4)Dry Rain tree $+\mathrm{NaOH}+\mathrm{HS}$ & 1.17 \\
\hline 5)Dry Rain tree $++\mathrm{Na}_{2} \mathrm{SO}_{4}$ & 1.52 \\
\hline 6)Dry Rain tree $+\mathrm{Na}_{2} \mathrm{SO}_{4}+\mathrm{HS}$ & 2.02 \\
\hline 7)Dry Rain tree $+\mathrm{NaOH}+\mathrm{Na}_{2} \mathrm{SO}_{4}$ & 2.30 \\
\hline 8)Dry Rain tree $+\mathrm{NaOH}+\mathrm{Na}_{2} \mathrm{SO}_{4}+\mathrm{HS}$ & 2.46 \\
\hline 9)Dry Rain tree $+\mathrm{HS}$ & 1.02 \\
\hline
\end{tabular}

From GC-MS results we have got more percentage of ethanol in wet jackfruit after fermentation. The percentage of ethanol in Wet jackfruit sample was found to be $4.34 \%$ and in dry Jackfruit leaves percentage of ethanol was found to be $4.23 \%$. We have selected wet Jackfruit leaves for the scale up production of bioethanol. 
The results obtained by performing experiments under pure Diesel mode and Ethanol blended diesel fuel mode and results are shown in Figs. 3-10.

Table 3. Properties of fuels

\begin{tabular}{|c|c|c|c|c|c|}
\hline \multirow{2}{*}{$\begin{array}{l}\text { Properties } \\
\text { Flash point }{ }^{\circ} \mathrm{C}\end{array}$} & \multicolumn{5}{|c|}{$\begin{array}{l}\text { Percentage of Ethanol blends with Diesel } \\
0 \% 5 \% 10 \% 15 \% 100 \%\end{array}$} \\
\hline & 53 & 51 & 43 & 37 & 16 \\
\hline Fire Point ${ }^{\circ} \mathrm{C}$ & 59 & 54 & 48 & 42 & 18 \\
\hline Density $\mathrm{Kg} / \mathrm{m}^{3}$ & 840 & 839.4 & 839.1 & 838.9 & 836 \\
\hline Kinematic Viscosity $\mathrm{mm}^{2} / \mathrm{sec}$ & 3.15 & 2.87 & 2.71 & 2.57 & 1.3 \\
\hline Calorific value MJ/kg & 43 & 42.7 & 42.48 & 42.21 & 19.2 \\
\hline
\end{tabular}

Open cup apparatus is used to determine Flash point and Fire point. Redwood viscometer is used to determine density and kinematic viscosity. Bomb calorimeter is used to determine Calorific value $[6,7,8]$.

\subsection{Brake specific fuel consumption(BSFC)}

The Fig. 3 illustrates the variation of BSFC with BP for Diesel, $5 \%$ blend, 10\% blend, $15 \%$ blends. The BSFC decreases with increase in BP for Diesel and for different blends. As compared to Diesel the BSFC are decreased for Ethanol fuel blends due to decrease in Calorific value. At $0.58 \mathrm{~kW}$ BP the difference between Diesel point and $15 \%$ ethanol blend point the BSFC is decreased by $8 \%$ compared to Diesel. At 4.11 kW BP we observed that there is $13 \%$ decrease in BSFC for $15 \%$ ethanol blend point than Diesel. So as the percentage of ethanol blend increases the BSFC value decreases respectively. Thus $15 \%$ ethanol blend has lower BSFC compared to other blends and Diesel for various loads [9].

\subsection{Brake thermal efficiency (BTE)}

The Fig. 4 illustrates the variation of BTE with BP for Diesel and different ethanol fuels blend. The BTE increases with increase in BP for both Diesel and ethanol fuel blends [10]. Due to lower calorific value and higher latent heat of vaporization as the percentage of ethanol fuel blends increases in Diesel the BTE increases as compared to diesel fuels. At $0.58 \mathrm{~kW} \mathrm{BP}$ we observed that there is $23 \%$ increase in BTE for $15 \%$ ethanol blend compared to Diesel. At $4.11 \mathrm{~kW}$ BP we observed that there is $14 \%$ increment in BTE for $15 \%$ ethanol fuel blend compared to Diesel. Thus for $15 \%$ ethanol blend has higher BTE compared to other ethanol blends and Diesel for different loads.

\subsection{Exhaust gas temperature (EGT)}


The Fig. 5 shows the variation of EGT with BP for Diesel and various percentage ethanol fuel blends. Exhaust gas temperature for ethanol fuel blends decreases as compared to Diesel because as the percentage of ethanol blend increases which increases the oxygen in the fuel blends which gives cooling effect to the engine hence reduces the exhaust gas temperature. Lower calorific value of ethanol fuel blends also decreases the exhaust gas temperature. For $0.58 \mathrm{~kW} \mathrm{BP}$ there is $11 \%$ decrease in exhaust gas temperature for $15 \%$ ethanol fuel blend as compared to Diesel. At $4.11 \mathrm{~kW} 9 \%$ decrease in exhaust gas temperature for $15 \%$ ethanol fuel blends compared to Diesel. Thus for $15 \%$ ethanol fuel blend has lower exhaust gas temperature compared to other blends and Diesel for various loads.

\subsection{Peak pressure rise}

The Fig. 6 illustrates the variation of Peak pressure rise with BP for Diesel and various percentages of ethanol blends. Ethanol has more content of oxygen and rapid combustion will occur hence sudden peak pressure rise was achieved. As the BP increases the peak pressure rise is higher in ethanol fuel blends and lower pressure rise in diesel for various loads. Thus $15 \%$ ethanol fuel blends is having higher peak pressure rise as compared to other fuel blend and diesel for various loads.

\subsection{Carbon monoxide (CO) emissions}

The Fig. 7 illustrates the variations of $\mathrm{CO}$ emissions with BP for Diesel and various ethanol blends. It is indicated that $\mathrm{CO}$ emissions are decreased with increase in percentage of ethanol blend compared to Diesel. Ethanol is oxygenated fuel so ethanol blends have more content of oxygen compared to diesel and gives complete combustion and also reduces the emissions of CO. At $0.58 \mathrm{~kW} \mathrm{BP}$ about $50 \%$ of $\mathrm{CO}$ emissions are reduced for $15 \%$ ethanol blend compared to diesel. At $4.11 \mathrm{~kW} \mathrm{BP}$ about $27 \%$ of $\mathrm{CO}$ emissions are reduced for $15 \%$ ethanol blend compared to diesel. Thus graph shows that $15 \%$ of ethanol blend has lower $\mathrm{CO}$ emissions compared to other ethanol fuel blends and diesel at various loads.

\subsection{Carbon Dioxide $\left(\mathrm{CO}_{2}\right)$ emissions}

The Fig. 8 illustrates the variation of Carbon Dioxide $\left(\mathrm{CO}_{2}\right)$ emissions with Brake power (BP) for various ethanol fuel blends and diesel. Due to more oxygen content in ethanol fuel blends complete combustion will occur. This result in decrease in $\mathrm{CO}_{2}$ emissions for ethanol blend compared to diesel. So as $\mathrm{BP}$ increase $\mathrm{CO}_{2}$ emissions will be reduced. At $0.58 \mathrm{~kW} \mathrm{BP}$ about $32 \%$ of $\mathrm{CO}_{2}$ emissions will be reduced for $15 \%$ ethanol fuel blend compared to diesel. At $4.11 \mathrm{~kW} \mathrm{BP}$ about $17 \%$ of $\mathrm{CO}_{2}$ emissions will be reduced for $15 \%$ ethanol fuel blends compared to diesel. Thus from above graph it is concluded that for $15 \%$ ethanol blend has lower $\mathrm{CO}_{2}$ emissions compared to other ethanol fuel blends and diesel at various loads.

\subsection{Hydrocarbon $(\mathrm{HC})$ emissions}

The Fig. 9 illustrates the variation of $\mathrm{HC}$ emissions with BP for various Ethanol blends and diesel. Ethanol blends having high latent heat of vaporization and low Cetane number, which reduces the exhaust gas temperature and promote the rapid combustion hence with increase in percentage of ethanol blends 
increases the Hydrocarbon emission compared to diesel. As Brake power increases hydrocarbon emissions also increases with increase in percentage of ethanol blends. At $0.58 \mathrm{~kW} \mathrm{BP}$ about $38 \%$ of hydrocarbon emissions will be increased for $15 \%$ ethanol blends compared to diesel similarly at $4.11 \mathrm{~kW}$ BP about $19 \%$ of hydrocarbon emissions will be increased for $15 \%$ ethanol blend than diesel. Thus the above graph shows that there will be increase in $\mathrm{HC}$ emissions for ethanol blends compared to diesel for various loads.

\section{$2.10 \mathrm{NO}$ Emissions}

The Fig. 10 illustrates the variation of $\mathrm{NO}_{\mathrm{x}}$ emissions with $\mathrm{BP}$ for various ethanol blends and diesel. The NOx formation is highly influenced by combustion temperature. From the graphs, it was observed that the NOx emission increases with the increase in load for diesel and various blended fuels. Moreover at all load ranges, the NOx emission is less for all blended fuels when compared with that of diesel. The high latent heat of vaporization and lower calorific value of ethanol reduces the cylinder temperature which in turn reduces the $\mathrm{NOx}$ emissions. At $0.58 \mathrm{~kW} \mathrm{BP}$ about $24 \%$ of $\mathrm{NO}_{\mathrm{x}}$ emissions were decreased for $15 \%$ ethanol blend compared to diesel. Similarly at $4.11 \mathrm{~kW} \mathrm{BP}$ about $13 \%$ of $\mathrm{NO}_{\mathrm{x}}$ emissions were decreased for $15 \%$ ethanol blend than diesel [11].

\section{Conclusion}

From results obtained following conclusions are made

1. In this present study, selected leaves wastes such as Rain tree leaves, Jackfruit tree leaves, Singapore cherry tree leaves, Mango tree leaves were considered as raw materials for the production of Bioethanol and the conversion of waste into fuel, which forms an attractive solution towards both waste management and Biofuels generation.

2. Due to more starch content in Jackfruit tree leaves and Rain tree leaves we have selected these leaves for the production of bioethanol. The percentage of ethanol from Gas Chromatography-Mass Spectrometry was found to be $4.34 \%$ in Wet Jackfruit tree leaves and $4.23 \%$ in Dry Jackfruit tree leaves. In Wet Rain tree leaves the percentage of ethanol was found to be $3.52 \%$ and in Dry Raintree leaves it was found to be $2.46 \%$.

3. The extracted Bioethanol from wet Jackfruit tree leaves wastes and analysis of fuel properties, the performance and emission characteristics of single cylinder $\mathrm{Cl}$ engine were carried out.

4. The Brake specific fuel consumption (BSFC) of ethanol blended diesel was decreased because ethanol blended diesel have lower calorific value and lower Cetane number compared to diesel. At $0.58 \mathrm{~kW}$ BP about $8 \%$ BSFC was decreased for $15 \%$ ethanol blend compared to diesel. At $4.11 \mathrm{~kW} \mathrm{BP}$ about $13 \%$ decrease in BSFC for $15 \%$ ethanol blend compared to diesel.

5. The Brake thermal efficiency (BTE) of ethanol blended fuel is increased with increase in Brake power (BP) as compared to diesel. This is because the ethanol blend diesel has more oxygen content and high latent heat of vaporization as compared to diesel which promotes the combustion. At $0.58 \mathrm{~kW}$ 
BP about 23\% BTE was increased and at $4.11 \mathrm{~kW}$ BP about 14\% BTE was increased compared to diesel.

6. The ethanol blend diesel has more oxygenated fuel compared to diesel and results in complete combustion. Hence $\mathrm{CO}$ emissions will be reduced for ethanol blend diesel compared to diesel. At $0.58 \mathrm{~kW}$ BP about $50 \%$ of $\mathrm{CO}$ emissions will be reduced and at $4.11 \mathrm{~kW}$ BP about $27 \%$ of CO emissions are reduced compared to diesel [12].

7. The ethanol blend fuel decreases the $\mathrm{CO}_{2}$ emissions compared to diesel because of complete combustion. At $0.58 \mathrm{~kW}$ BP about $32 \%$ of $\mathrm{CO}_{2}$ emissions are reduced and at $4.11 \mathrm{~kW}$ BP about $17 \%$ of $\mathrm{CO}_{2}$ emissions are reduced compared to diesel.

8. Due to rapid combustion the hydrocarbon emissions will be more for ethanol blend diesel compared to diesel. At $0.58 \mathrm{~kW}$ BP about $38 \%$ of $\mathrm{HC}$ emissions will be increased and at $4.11 \mathrm{~kW}$ BP about $19 \%$ oh HC emissions are increased compared to diesel for Jackfruit leaves ethanol [13].

9. NOx emission increases with the increase in load for diesel and various blended fuels. Moreover at all load ranges, the NOx emission is less for all blended fuels when compared with that of diesel. The high latent heat of vaporization and lower calorific value of ethanol reduces the cylinder temperature which in turn reduces the NOx emissions. At $0.58 \mathrm{~kW}$ BP about $24 \%$ of $\mathrm{NO}_{\mathrm{x}}$ emissions were decreased for $15 \%$ ethanol blend compared to diesel. Similarly at $4.11 \mathrm{~kW}$ BP about $13 \%$ of $\mathrm{NO}_{\mathrm{x}}$ emissions were decreased for $15 \%$ ethanol blend than diesel.

\section{Materials And Methods}

\subsection{Microorganism and Culture media}

The media was prepared with $22.75 \mathrm{~g}$ of Sabouraud Dextrose Agar (SDA) in $350 \mathrm{ml}$ of distilled water in a $1000 \mathrm{ml}$ conical flask and mixed well thoroughly, which was plugged with cotton plug and sterilized or autoclaved for $30 \mathrm{~min}$ at $15 \mathrm{psi}$ and $121^{\circ} \mathrm{C}$. Then the media is allowed to cool to the room temperature and the medium is equally distributed petri dishes in laminar flow chamber. The SDB media was prepared by adding $65 \mathrm{~g}$ of Sabouraud Dextrose Broth (SDB) to $1000 \mathrm{ml}$ of distilled water and mixed well thoroughly which was plugged with cotton plug and autoclaved (sterilized) for 30 minutes at 15psi and $121^{\circ} \mathrm{C}$. Sabouraud Dextrose Broth (SDB) with an organism is allowed to grow for 24 hours.

\subsection{Collection of raw material}

Lignocellulosic dry and wet leaves such as Rain tree leaves, Jackfruit leaves, Singapore cherry leaves, Mango tree leaves were taken from agricultural rural areas [14]. All the leaves samples were dried and grounded into powder.

\section{3 lodine test to determine starch content in leaves}

The iodine test is conducted to determine the starch content in the different plant leaves. The plant leaves have green parts (where the cells contains chlorophyll) and white parts (where there is no chlorophyll). 
Only the parts that were green becomes blue black with iodine solution. From this test we observed that there is more starch content in Jackfruit and Rain tree leaves compared to Mango tree and Singapore cherry leaves [15]. We selected Rain tree and Jackfruit tree leaves for the production of bioethanol.

\subsection{Extraction of juice from different plant wastes}

About $50 \mathrm{~g}$ of wet leaves of Rain tree and jackfruit trees are weighed separately and which was rinsed with water and then washed and added $250 \mathrm{ml}$ of distilled water. The wet leaves of rain tree and jackfruit trees were separately crushed in a mixer and stored in a conical flask. Similarly the dry leaves of the jackfruit trees and rain trees are collected and cleaned with distilled water and dried in sunlight for reduction of moisture content in the leaves [16]. About $500 \mathrm{~g}$ of dry leaves of both trees were weighed separately and $25 \mathrm{~g}$ of each plant wastes are taken in 10 different $250 \mathrm{ml}$ conical flask and $100 \mathrm{ml}$ of water is added.

\subsection{Fermentation process}

The $250 \mathrm{ml}$ juice of wet leaves of both rain trees and jackfruit trees are taken in $500 \mathrm{ml}$ conical flask and which were plugged with cotton plug. The content was autoclaved for 30 minutes at $15 \mathrm{psi}$ and $121^{\circ} \mathrm{C}$. The $25 \mathrm{~g}$ of each dry rain tree and jackfruit tree leaves are weighed separately and were taken separately in 9 different $250 \mathrm{ml}$ conical flasks and $100 \mathrm{ml}$ of distilled water is added for each conical flask [17].

$750 \mathrm{mg}$ of sodium hydroxide is added for 2 conical flasks of each plant leaves Heat Shock treatment is given for 1 conical flask of each samples.

$750 \mathrm{mg}$ of sodium sulphate is added for another 2 conical flasks of each plant leaves and Heat Shock treatment is given for 1 conical flask of each samples.

$750 \mathrm{mg}$ of each sodium hydroxide and sodium sulphate is added for another 2 conical flasks of each plant leaves and Heat Shock treatment is given for 1 conical flask of each samples.

For remaining 3 conical flasks of each plant leaves no chemicals were added. Only control is maintained. Heat Shock (HS) is given for 1 conical flask at 10 power 5 minutes of each leaves and remaining 2 conical flasks were used for biochemical tests and were plugged with cotton plug and were autoclaved for 30 minutes at $15 \mathrm{psi}, 121^{\circ} \mathrm{C}$. Pre-treatment of lingo cellulose biomass by microwave irradiation is based on non-thermal and thermal effects of microwaves. Heating is very essential parameter in pretreatment technology. Higher temperature accelerates the reaction rate and minimizes the chemicals requirement during pre-treatment [18].

The process was continued to find the $\mathrm{pH}$ values of specimens by using $\mathrm{pH}$ paper method. These contents were allowed to cool and $10 \%$ of Saccharomyces cerevisiae culture was inoculated in 9 different $250 \mathrm{ml}$ conical flask of each plant leaves in laminar air flow chamber. The media was incubated for 10 days at $27 \pm 2{ }^{\circ} \mathrm{C}$ temperature, $80 \mathrm{rpm}$ in rotary shaker incubator [19]. After 10days of incubation the media was filtered and centrifuged at $13000 \mathrm{rpm}$ for 10 minutes to remove cell and suspended particles. 
The supernatant was collected and Gas chromatography and mass spectrometry (GC-MS) test was conducted for the estimation of ethanol content [20].

\subsection{Determination of Carbohydrate by Anthrone Reagent method}

The major constraint beyond the carbohydrate estimation is that carbohydrates are dehydrated with concentrated $\mathrm{H}_{2} \mathrm{SO}_{4}$ to form furfural. This furfural condenses with Anthrone reagent to form green colour which is measured by calorimeter at $670 \mathrm{~nm}$. Anthrone reagent was prepared by dissolving $100 \mathrm{mg}$ of Anthrone reagent in $50 \mathrm{ml}$ of concentrated Sulphuric acid [21]. Standard Glucose was prepared by Adding $100 \mathrm{mg}$ of Glucose or Maltose to $50 \mathrm{ml}$ of distilled water.

\subsection{Engine setup}

The experiments were conducted on 4 Stroke, Single Cylinder Diesel engine with electrical loading is as shown in Fig. 11.

1. 1. Diesel engine 2.Generator 3.Electrical load

2. 4. Fuel tank 5.Pressure pickup 6.Shaft encoder 7. Computer 8.Exhaust gas analyzer

3. 9. Exhaust temperature measurement meter

4. 10. Data acquisition system

Table 4

Engine specifications

\begin{tabular}{|ll|}
\hline Company & Kirloskar \\
\hline Engine type & Four Stroke Single Cylinder \\
\hline Power & $5.2 \mathrm{~kW}$ \\
Stroke & $110 \mathrm{~mm}$ \\
\hline Speed & $1500 \mathrm{rpm}$ \\
\hline Compression Ratio & $17.5: 1$ \\
\hline Cooling & Water Cooled \\
\hline Fuel injection & Mechanical injection with injection timing 23ํTDC \\
\hline Injection pressure & 210 bar \\
\hline
\end{tabular}

\subsubsection{Exhaust gas analyser}

AVL DIGAS 440 gas analyser as shown in Fig. 12 is a device used to measure the emissions. 
Table 5

Data showing the

measurement resolution of

emissions

\begin{tabular}{|ll|}
\hline Emissions & Resolutions \\
\hline $\mathrm{HC}$ & $1 \mathrm{ppm}$ \\
\hline $\mathrm{CO}$ & $0.01 \%$ \\
\hline $\mathrm{CO}_{2}$ & $0.01 \%$ \\
\hline $\mathrm{O}_{2}$ & $0.01 \%$ \\
\hline $\mathrm{NO}_{\mathrm{X}}$ & $1 \mathrm{ppm}$ \\
\hline
\end{tabular}

\section{Abbreviations}

BSFC: Brake specific fuel consumption; BTE: Brake thermal efficiency; EGT: Exhaust gas temperature; HC: Hydrocarbon; BP: Brake power; SDA: Sabouraud Dextrose Agar; SDB: Sabouraud Dextrose Broth; HS: Heat Shock; GC-MS: Gas chromatography and mass spectrometry.

\section{Declarations}

\section{Acknowledgements}

I would like to acknowledge SAVI EASY LIFE s.r.o., and Springer Nature team for their support.

\section{Authors' contributions}

Dr. Ir. Sreenivas Reddy Bathula conducted fermentation related work including manuscript preparation; Vikas S Ballary mechanical lab work; Dr. Kumarappa engine data analysis; Guruchethan A.M. produced figures, graphs and conducted $\mathrm{Cl}$ engine studies; Harika Mali contributed to the discussion and results analysis. All authors contributed to editing the manuscript. All authors read and approved the final manuscript.

\section{Funding}

This research received no specific grant from any funding agency in the public, commercial, or not-forprofit sectors.

\section{Availability of data and material}

The authors confirm that the data supporting the findings of this study are available within the reference articles and in its supplementary materials. 
Not applicable

\section{Consent for publication}

Not applicable

\section{Competing interests}

The authors declare that they have no known competing financial interests or personal relationships that could have appeared to influence the work reported in this paper.

\section{Author details}

${ }^{1}$ Adama Science \& Technology University, P.O Box 1888, Adama, Ethiopia. Email id:

sreenivas.reddy@astu.edu.et ; Mobile No: +251-988683641

${ }^{2}$ Dept of Mechanical Engg, BIET Davangere, Karnataka, India.

${ }^{3}$ SAVI EASY LIFE s.r.o., Czech Republic.

\section{References}

1. Saravana C, Murugan, Rajendran S. Bioethanol Production from Agave Leaves Using Saccharomyces cerevisiae (MTCC 173) and Zymomonas mobilis (MTCC 2427). Int J Microbiol Res. 2013;4(1):23-6.

2. Elsa Cherian, Dharmendira Kumar M, Baskar G. Cellulosic bioethanol production by sequential fermentation using agriculture waste. International Journal of Chem Tech Research. 2014;6(14):5653-60.

3. Corbin KR, Byrt CS, Bauer S, DeBolt S, Chambers D, Holtum JA, Karem G, Henderson M, Lahnstein J, Beahan CT, Bacic A, Fincher GB, Betts NS, Burton RA. Prospecting for Energy-Rich Renewable Raw Materials: Agave Leaf Case Study. PLoS One. 2015;10(8).

4. Dhurjati. Method for the production of bioethanol from Muntingia calabura from Saccharomyces cerevisiae. 2014;25:patent number. 260312.

5. Shrikant BS, Thakor NJ, Haldankar PM, Kalse SB. A Review on Jackfruit and Its Many Functional Components as Related to Human Health. 2012;11(6):565-576.

6. Devarajan Y, Munuswamy DB, Nagappan B. Emissions analysis on diesel engine fuelled with cashew nut shell biodiesel and pentanol blends. Environ Sci Pollut Res Int. 2017;24(14):13136-41.

7. Ravishankar BV, Vikas SB, Akarsh MR, Rangaswamy BE, Bathula SR. Production of Bio-ethanol from an Underexploited Fruit of Muntingia calabura and Studying Performance and Emission Characteristics of Single Cylinder CI Engine. Bioprocess Eng. 2017;1(1):1-6. 
8. Sulakshana SD, Channapattana SV, Pawar AA. Experimental Evaluation of Diesel Engine Performance and Emissions Using Diesel/Biodiesel/Ethanol Blend Fuel, International Journal of Emerging Technology and Advanced Engineering. 2015;5(1).

9. Ashfaque Ahmed S, Prabhakar S, Binu KS, Irshad Ahmed M. Performance test for Lemon grass oil in twin cylinder diesel engine, ARPN Journal of Engineering and Applied Sciences. 2013; 8(6).

10. Comparative Studies on Performance Ragit SS, Mohapatra SK, Kundu K. Comparative Studies on Performance.

11. Characteristics of $\mathrm{Cl}$ Engine Fuelled. with Neem Methyl Ester and Mahua Methyl.

12. Ester and Its Respective Blends with Diesel Fuel. J Environ Sci Eng. 2014;56(1):73-8.

13. Attempts to minimize nitrogen oxide emission from diesel engine by using Rashedul HK, Kalam MA, Masjuki HH, Teoh YH, How HG, Monirul IM, Imdadul HK. Attempts to minimize nitrogen oxide emission from diesel engine by using.

14. antioxidant treated diesel-biodiesel blend. Environ Sci Pollut Res Int. 2017;24(10):9305-13.

15. Premnath S, Devaradjane G. Improving the performance and emission characteristics of a single cylinder diesel engine having reentrant combustion chamber using diesel and Jatropha methyl esters. Ecotoxicol Environ Saf. 2015;121:10-5.

16. Experimental investigation of homogeneous

Ganesh D, Nagarajan G, Ganesan S. Experimental investigation of homogeneous.

17. charge compression ignition combustion of biodiesel fuel with external mixture.

18. formation in. a Cl engine. Environ Sci Technol. 2014;48(5):3039-46.

19. Budzianowska A, Budzianowski J. [Tobacco-a source of biofuels]. Przegl Lek. 2012;69(10):114952.

20. Masahide Yasuda H, Nagai K, Takeo Y, Ishii. Bio-ethanol production through simultaneous saccharification and co-fermentation (SSCF) of a low-moisture anhydrous ammonia (LMAA)pretreated napie grass. Springerplus. 2014;3:333.

21. Surendra PS, Kumar S, Mishra I, Adhikari DK. Recent Advances in Production of Bioethanol from Lignocellulosic Biomass. chemical engineering technology. 2009;32(4):517-26.

22. Panagiotopoulos IA, Chandra RP, Saddler JN. A two-stage pretreatment approach to maximise sugar yield and enhance reactive lignin recovery from poplar wood chips. Bioresour Technol. 2013;130:570-7.

23. Rokeyoh S, Kanokphorn S, Chompoonuch W. Conversion of leaf waste to sugar and ethanol by SHF and SSF fermentation using cellulase from cellulomonas sp. International Journal of Advanced Biotechnology Research. 2011;2(3):345-9.

24. Nyachaka CJ, Yawas DS, Pam GY. Production And Performance Evaluation Of Bioethanol Fuel From Groundnuts Shell Waste. American Journal of Engineering Research. 2014;2(12):303-12.

25. Martins MT, de Souza WR, da Cunha BA, Basso MF, de Oliveira NG, Vinecky F, Martins PK, de Oliveira PA, Arenque-Musa BC, de Souza AP, Buckeridge MS, Kobayashi AK, Quirino BF, Molinari HB. 
Characterization of sugarcane (Saccharum spp.) leaf senescence: implications for biofuel production. Biotechnol Biofuels. 2016;9:153.

26. Jin Y, Huang T, Geng W, Yang L. Comparison of sodium carbonate pre-treatment for enzymatic hydrolysis of wheat straw stem and leaf to produce fermentable sugars. Bioresour Technol. 2013;137:294-301.

\section{Supplementary Information}

Supplementary information accompanies this paper

Additional file 1: Comparison of Ethanol percentage in various Jackfruit sample

Additional file 2: Comparison of ethanol percentage in Rain tree leaves sample

Additional file 3: Variation of BSFC with BP for Diesel and various blend of ethanol

Additional file 4: Variation of BTE with BP for Diesel and various blend of ethanol

Additional file 5: Variation of EGT with BP for Diesel and various blend of ethanol

Additional file 6: Variation of Peak pressure rise with BP for Diesel and various blend of ethanol

Additional file 7: Variation of $\mathrm{CO}$ emissions with BP for Diesel and various blend of ethanol

Additional file 8: Variation of $\mathrm{CO} 2$ emissions with BP for Diesel and various blend of ethanol

Additional file 9: Variation of $\mathrm{HC}$ emissions with BP for Diesel and various blend of ethanol

Additional file 10: Variation of NOx emissions with BP for Diesel and various blend of ethanol

Additional file 11: Line diagram of single cylinder, four stroke Diesel engine

Additional file 12: Exhaust gas analyser

\section{Figures}




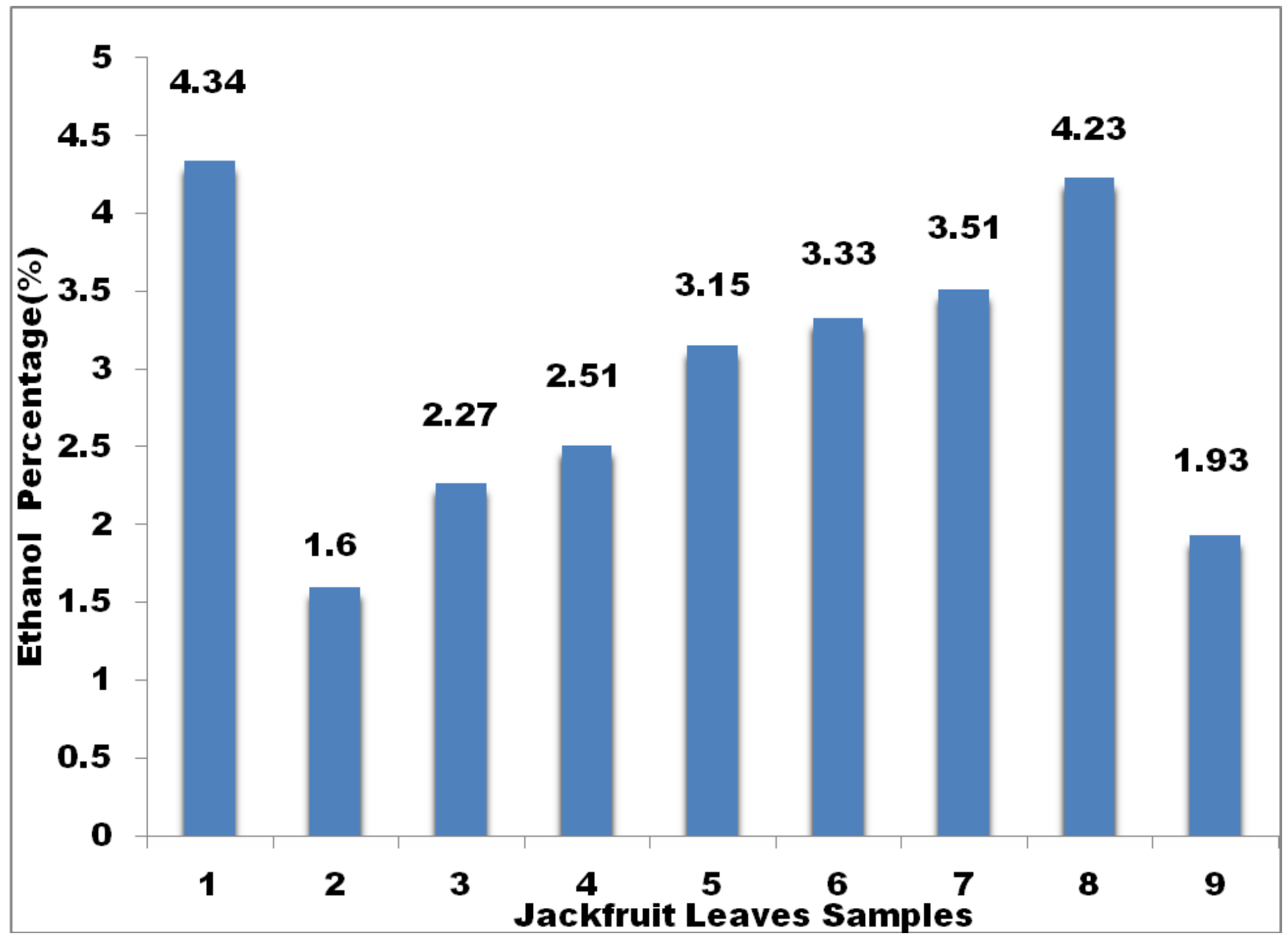

Figure 1

Comparison of Ethanol percentage in various Jackfruit sample 


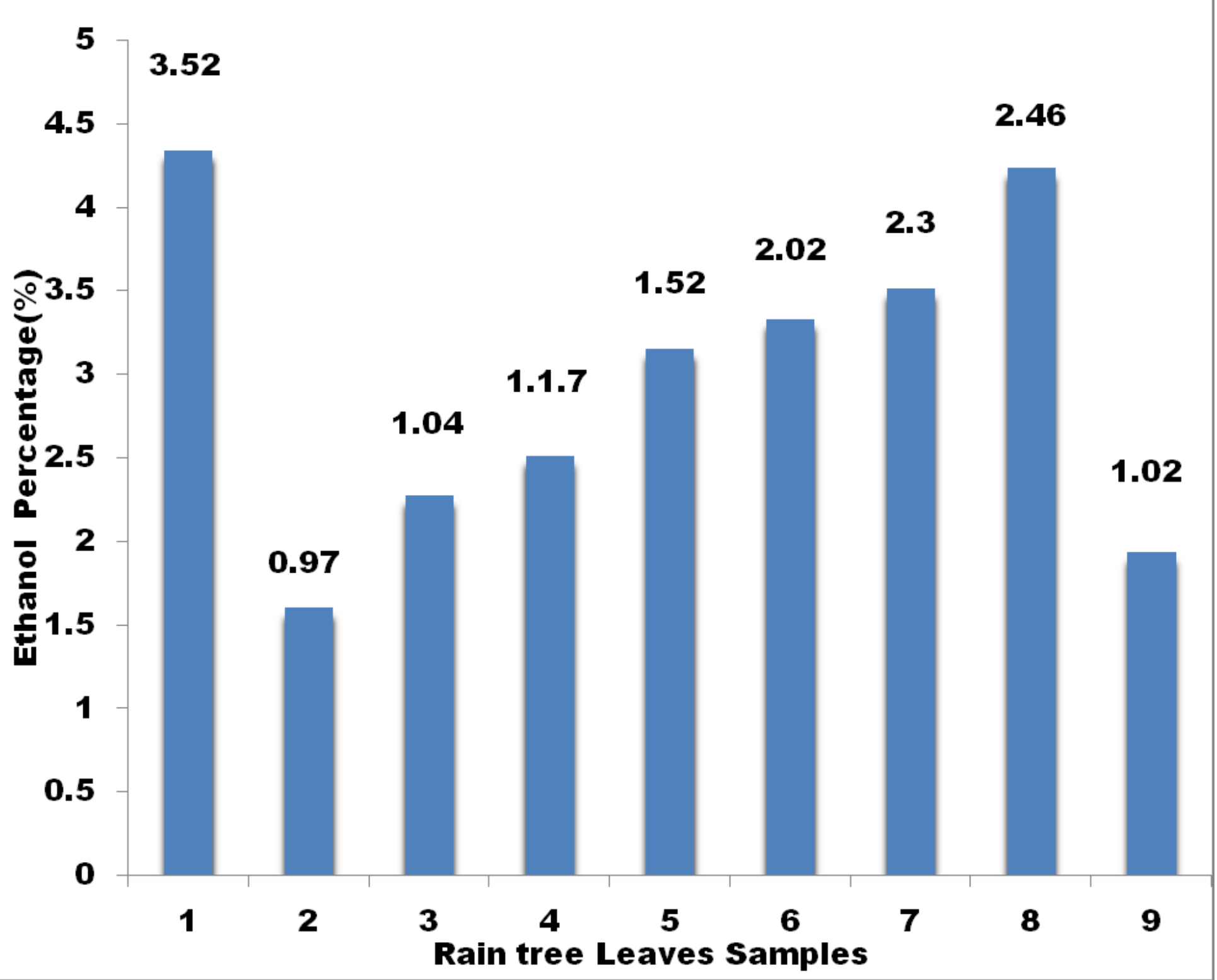

Figure 2

Comparison of ethanol percentage in Rain tree leaves sample. 


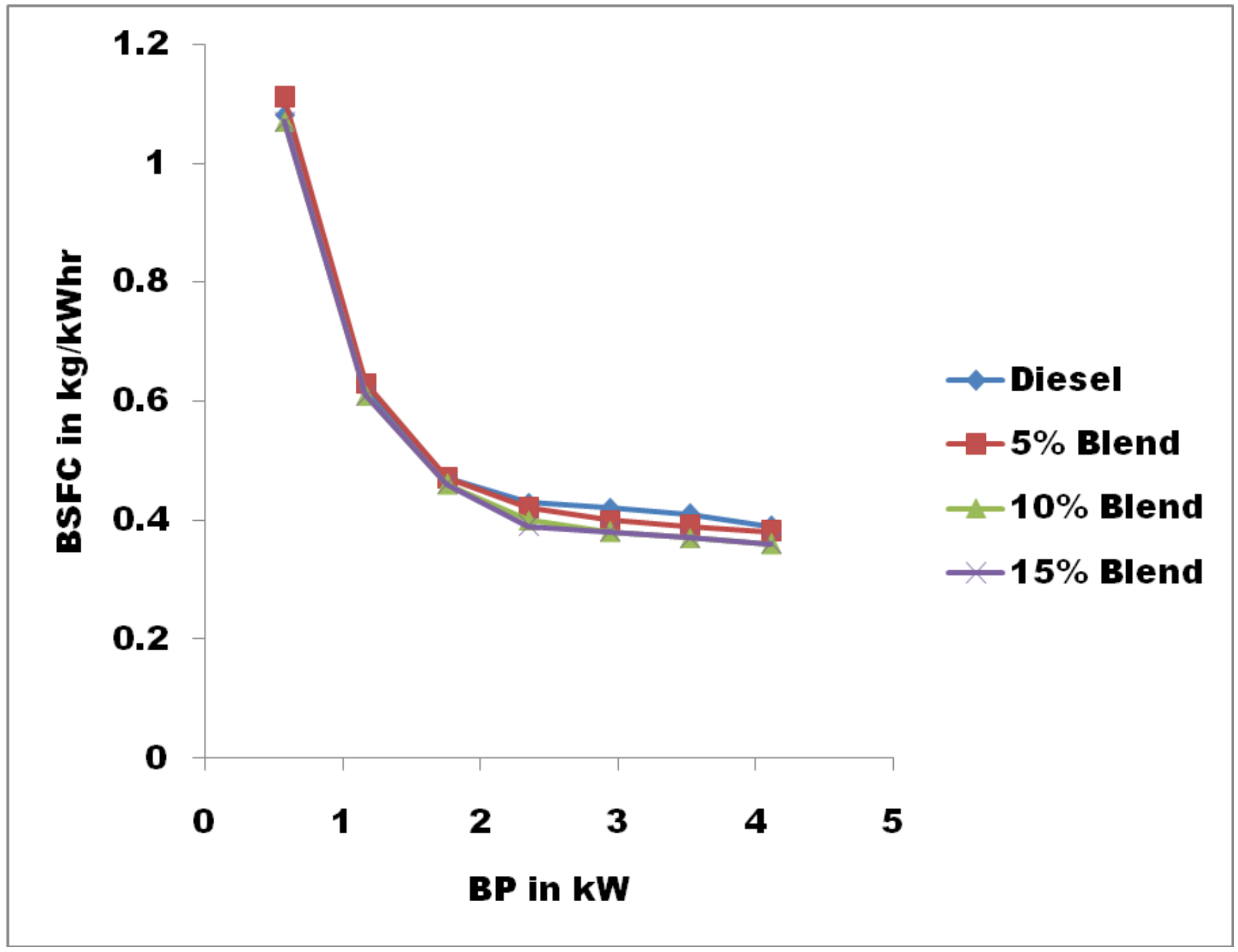

Figure 3

Variation of BSFC with BP for Diesel and various blend of ethanol 




Figure 4

Variation of BTE with BP for Diesel and various blend of ethanol 


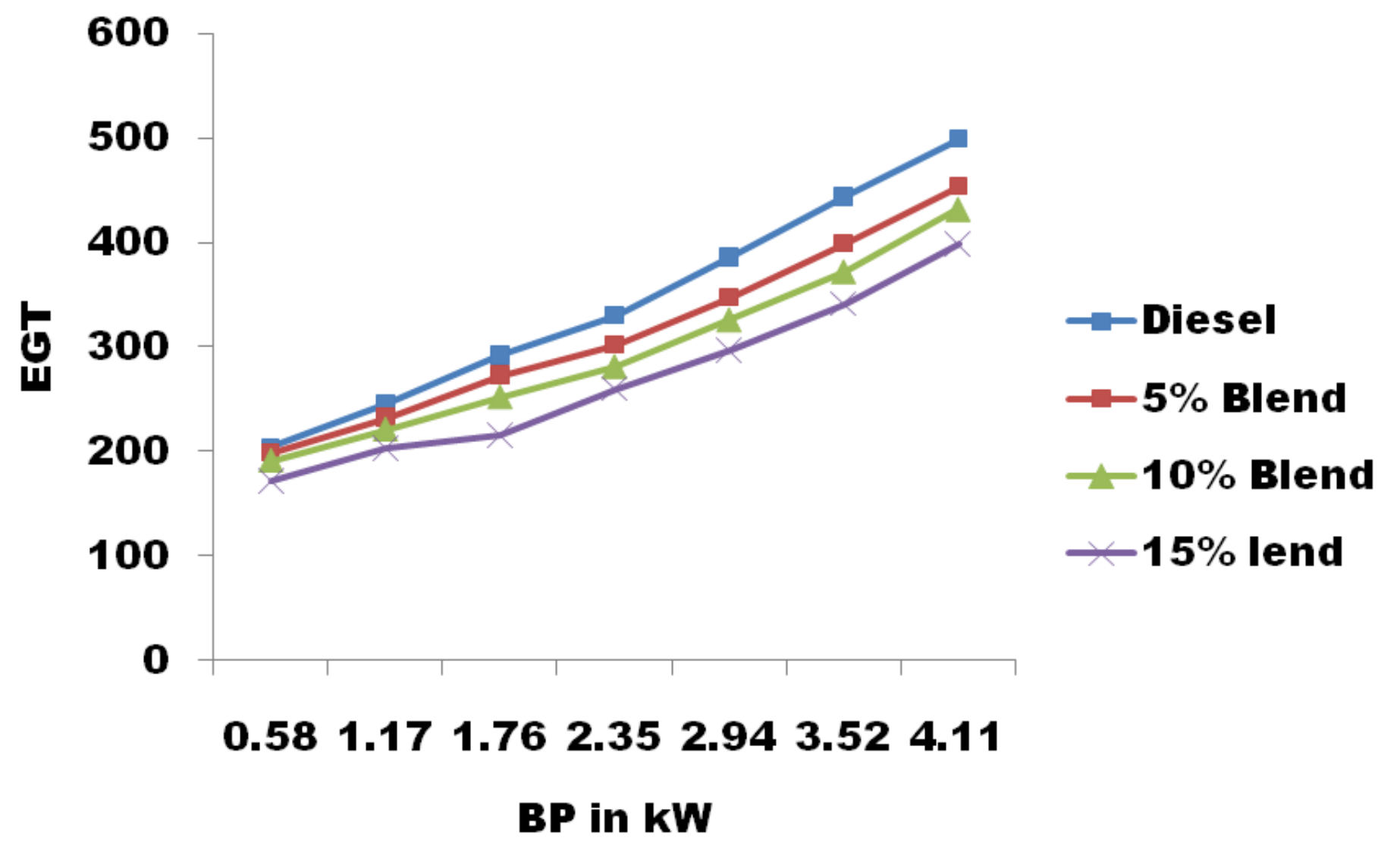

Figure 5

Variation of EGT with BP for Diesel and various blend of ethanol

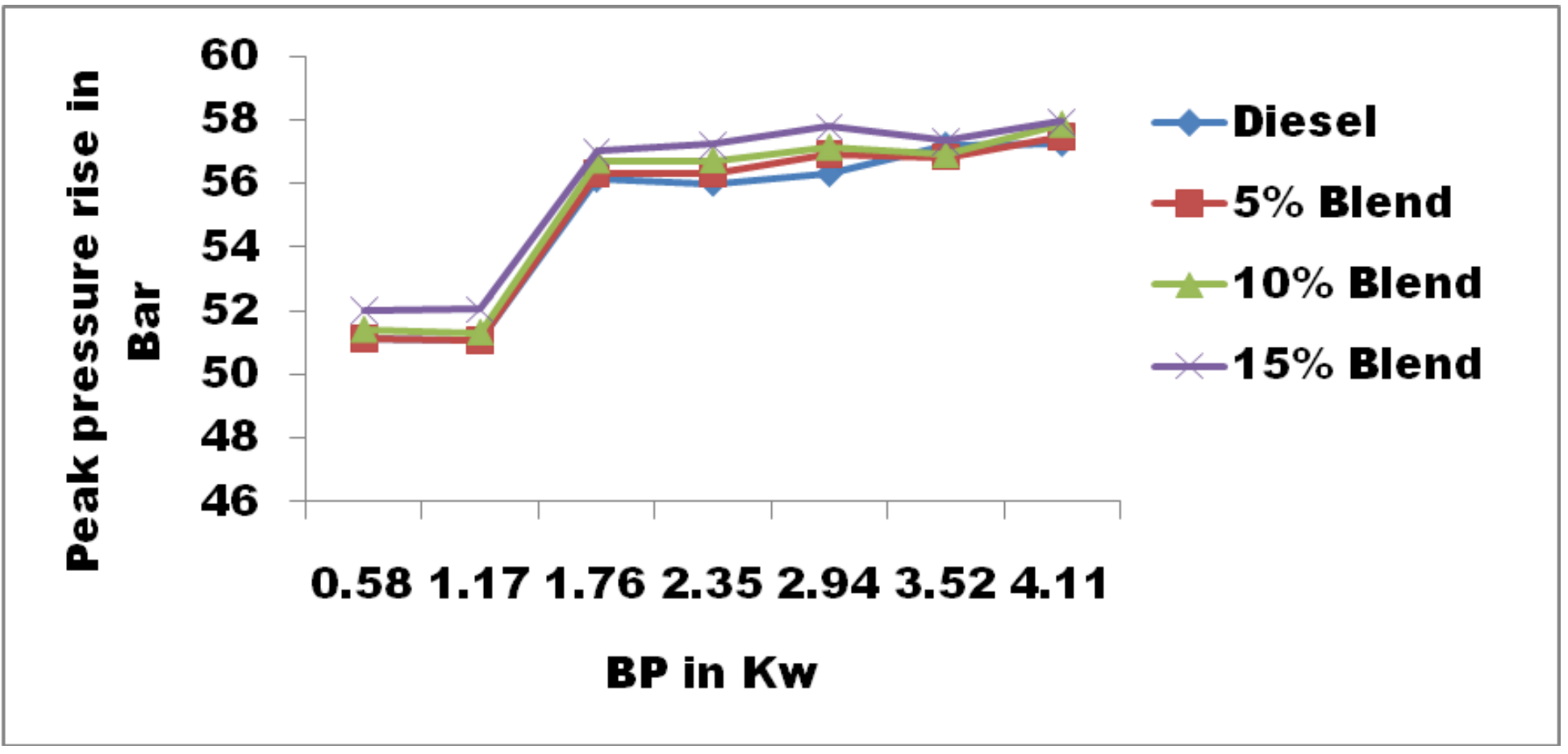

Figure 6 


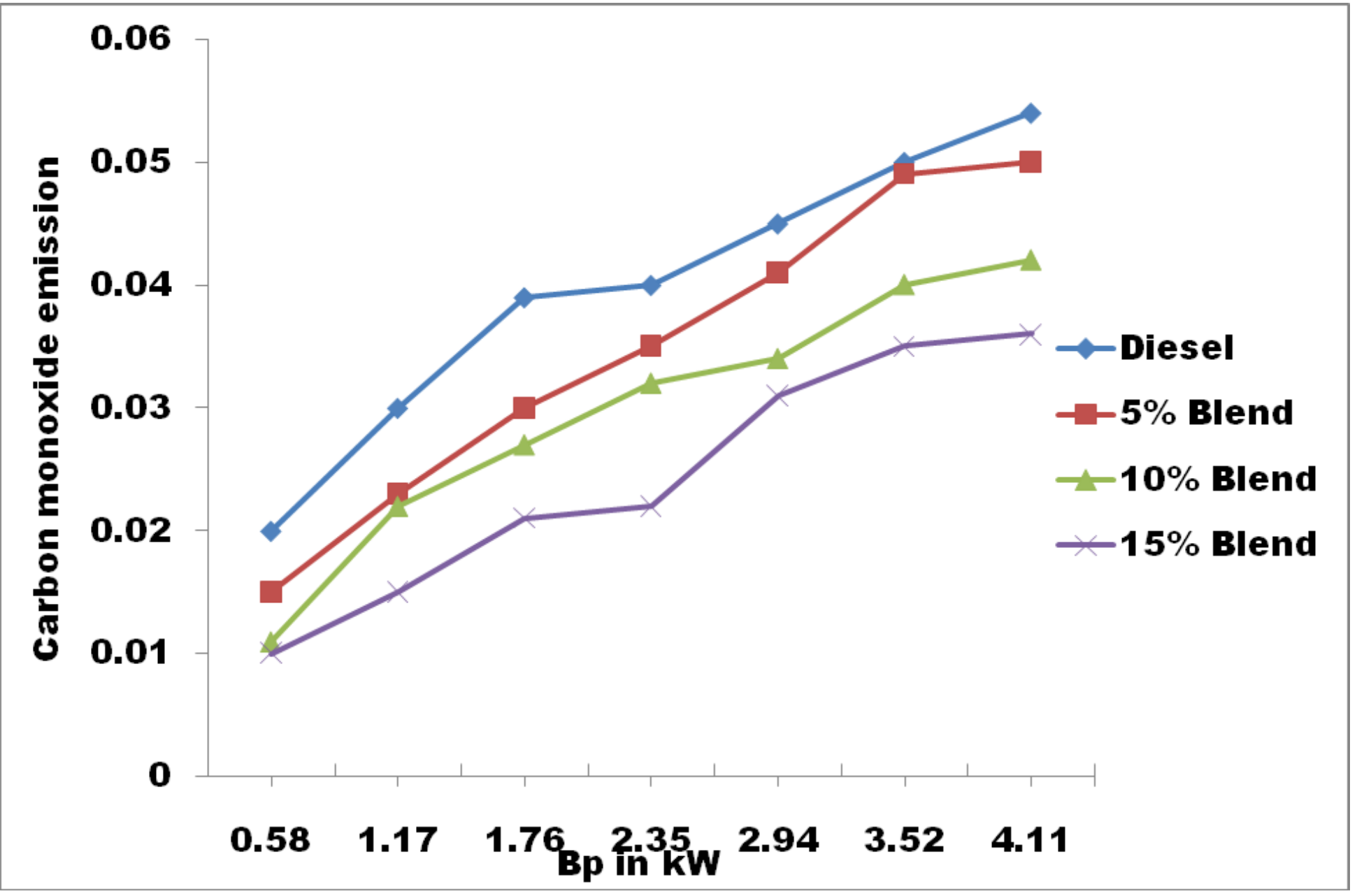

Figure 7

Variation of $\mathrm{CO}$ emissions with $\mathrm{BP}$ for Diesel and various blend of ethanol 


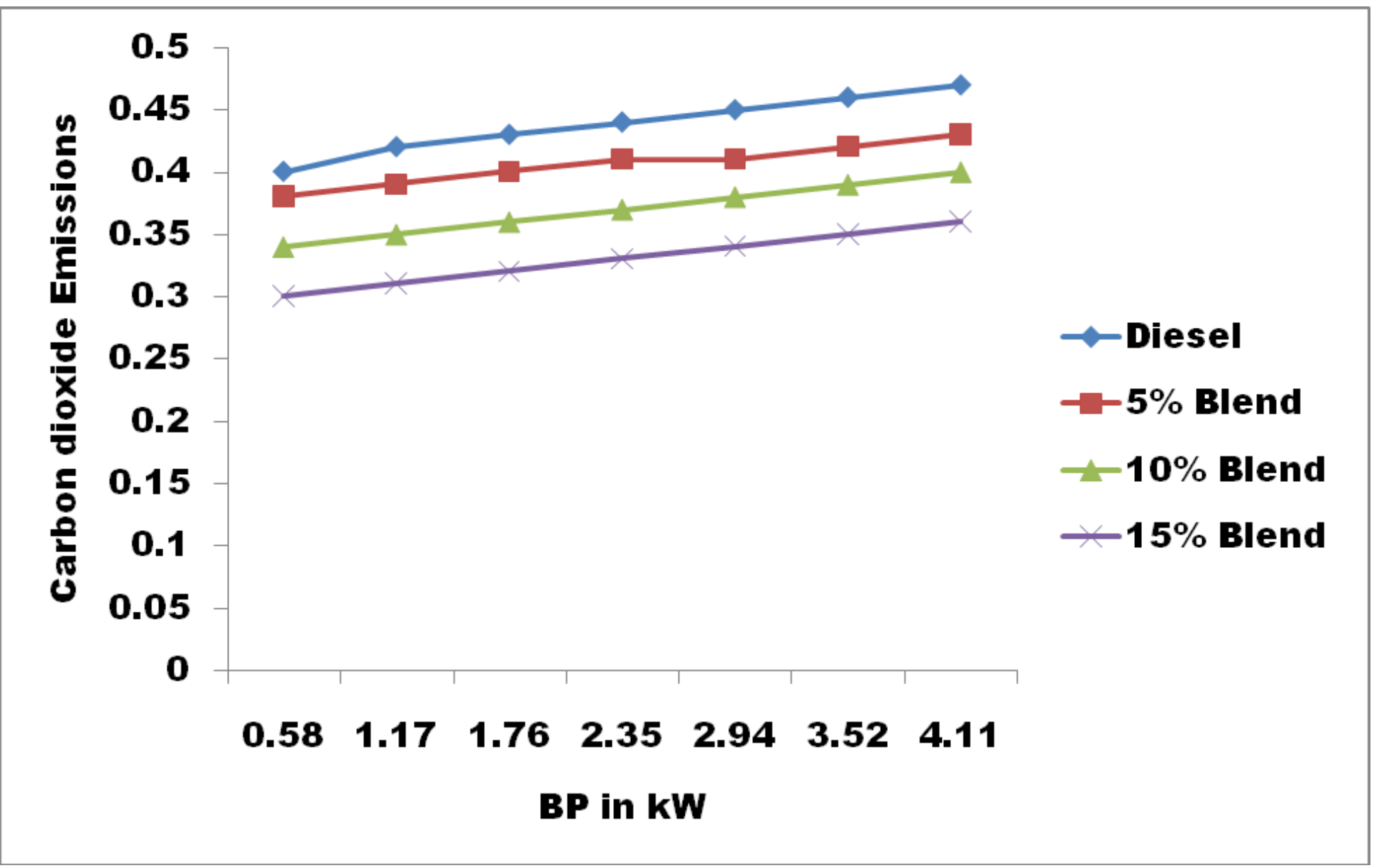

Figure 8

Variation of $\mathrm{CO} 2$ emissions with BP for Diesel and various blend of ethanol 


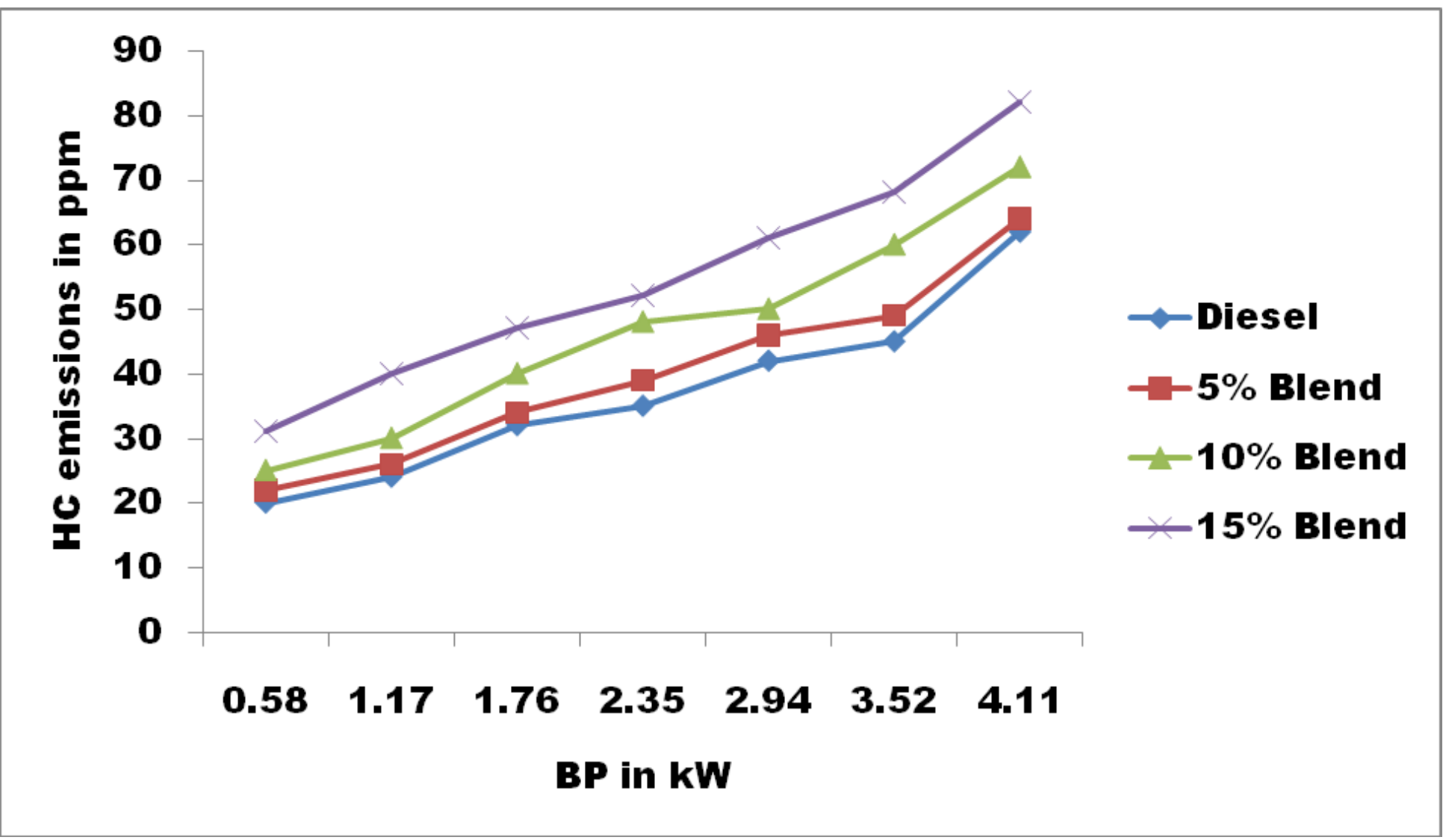

Figure 9

Variation of $\mathrm{HC}$ emissions with $\mathrm{BP}$ for Diesel and various blend of ethanol 




Figure 10

Variation of NOx emissions with BP for Diesel and various blend of ethanol

\section{Supplementary Files}

This is a list of supplementary files associated with this preprint. Click to download.

- Supportingdata.docx 